\title{
AN ASSESSMENT OF THE IMPACT OF HIV/AIDS ON ECONOMIC GROWTH: THE CASE OF KENYA
}

\author{
MAUREEN WERE \\ NANCY N. NAFULA
}

CESIFO WORKING PAPER NO. 1034

CATEgORY 5: Fiscal Policy, Macroeconomics AND Growth

SEPTEMBER 2003

Presented at CESifo Conference on Health and Economic Policy, June 2003
An electronic version of the paper may be downloaded
- from the SSRN website:
www.SSRN.com
- from the CESifo website:
www.CESifo.de 


\title{
AN ASSESSMENT OF THE IMPACT OF HIV/AIDS ON ECONOMIC GROWTH: THE CASE OF KENYA
}

\begin{abstract}
HIV/AIDS pandemic in Africa has been closely associated with adverse economic effects, and could thwart the success of poverty reduction initiatives. HIV/AIDS is fast eroding the health benefits, which Kenya gained in the first two decades of independence. The paper explores the different channels through which HIV/AIDS affects economic growth in a lowincome country like Kenya. Within this framework, the paper attempts to analyse the impact of HIV/AIDS on Kenya's economic growth by way of simulations using a macroeconomic model for the Kenyan economy. Some of the key channels explored are the impact of HIV/AIDS on productivity and labour force supply; asset accumulation of human, physical and social capital; and the gender channel.
\end{abstract}

JEL Code: E17, I10.

Maureen Were

Nancy N. Nafula

Kenya Institute for Public Policy Research and Kenya Institute for Public Policy Research and Analysis (KIPPRA)

$2^{\text {nd }}$ Floor, Bishops Garden Towers

Bishops Road

P.O.Box 56445

Nairobi

Analysis (KIPPRA)

Kenya

maureen_were@yahoo.com

$2^{\text {nd }}$ Floor, Bishops Garden Towers

Bishops Road

P.O.Box 56445

Nairobi

Kenya

nafula@kippra.or.ke

We are grateful to Professor Germano Mwabu of University of Nairobi for his valuable comments as a discussant to an earlier draft presented at the CESifo conference on Health and Economic Policy and to Mr. Nassor S. Nassor of the University of Dar es salaam for the insight provided. However, the authors are responsible for any errors and omissions. 
ACKNOWLEDGEMENTS _................................................................................... II

ABSTRACT

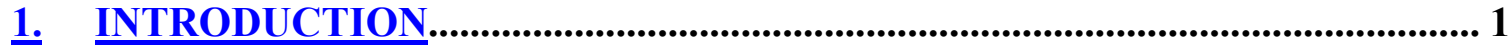

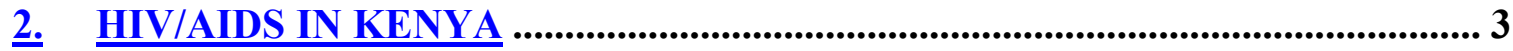

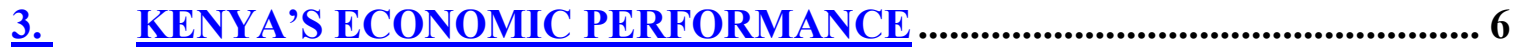

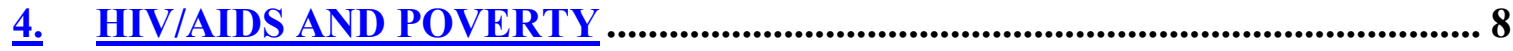

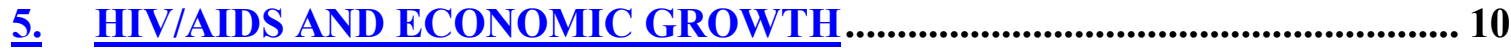

5.1 ASSET ACCUMULATION AND TECHNOLOGICAL CHANNELS ............................... 10

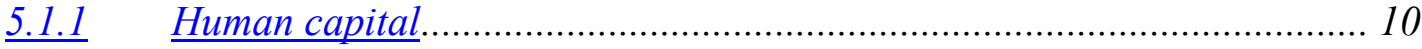

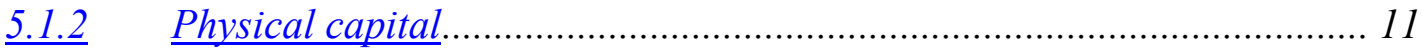

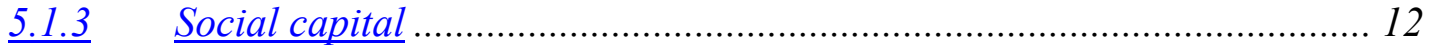

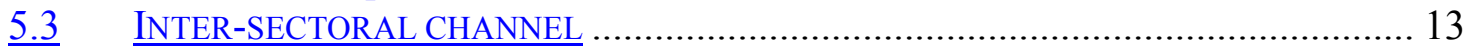

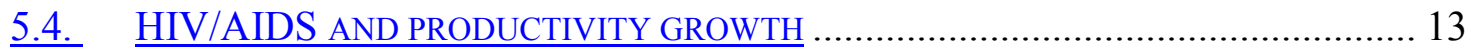

5.4.1 Impact on Working Population ................................................................... 13

5.4.2 Impact on productivity of Women .................................................... 14

$\underline{5.4 .3} \quad$ Impact on manufacturing Firms and other work places.......................... 15

5.4.4 Impact on Agriculture .................................................................... 16

6. QUANTIFYING THE IMPACT OF HIV/AIDS ON GDP GROWTH.............. 17

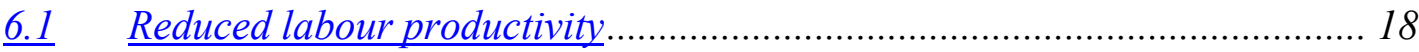

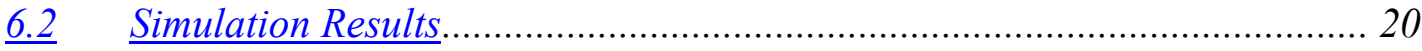

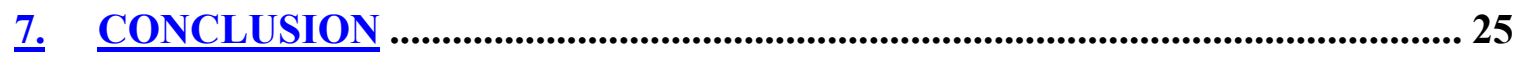




\section{LIST OF TABLES}

Table 1: Numbers of people (millions) worldwide living with HIV and AIDS in 2001 .... 1

Table 2: Estimated HIV Prevalence, 1998 - 2002 ........................................................... 4

Table 3: Percentage of pregnant women testing positive at urban sentinel surveillance sites 5

Table 4: Demographic Indicators 1963 - 2000 ........................................................... 7

Table 5:Average Annual Growth Rates (\%) of Real GDP, 1964-2002 …......................... 7

Table 6: Performance of key real macroeconomic aggregates ........................................ 8

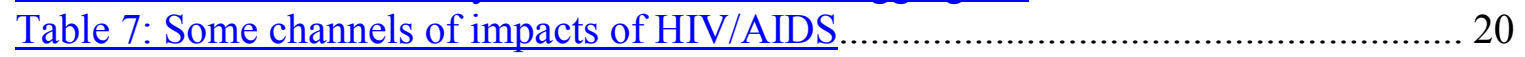

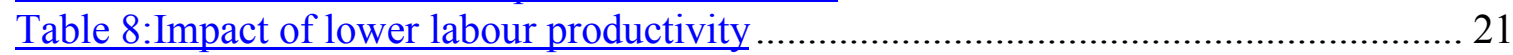

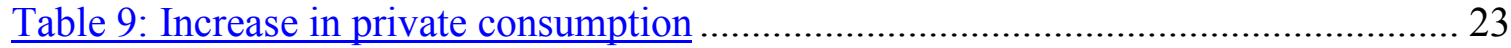

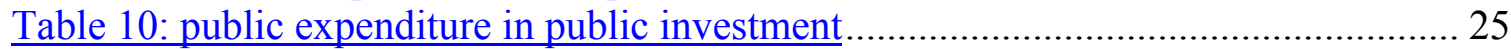

\section{LIST OF FIGURES}

Figure 1: Age-sex distribution of reported AIDS cases (1986-2000) ............................... 5

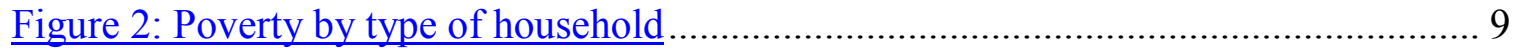




\section{ACRONYMS}

HIV Human Immuno Deficiency Virus

AIDS Acquired Immune Deficiency Syndrome

SSA Sub-Saharan Africa

VCTs Voluntary Counselling and Testing

SNA Systems of National Accounting 


\section{INTRODUCTION}

Human Immunodeficiency Virus/Acquired Immunodeficiency Syndrome (HIV/AIDS) prevalence has become a major international concern, particularly in Africa where it has taken a heavy toll. Africa has the highest number of new infections. Africa is home to about $70 \%$ of the adults and $80 \%$ of the children living with HIV in the world. The estimated number of newly infected adults and children in Africa reached 3.5 million at the end of 2001. It has also been estimated that 28.5 million adults and children were living with HIV/AIDS in Africa by the end of 2001, with Sub-Saharan Africa (SSA) accounting for $70 \%$ of adults and children living with HIV/AIDS in the world (see Table 1). SSA remains the most severely affected region in the world. AIDS deaths totaled 3 million globally in 2001, and of the global total 2.2 million AIDS deaths occurred in Africa (UNAIDS 2002). When HIV/AIDS was first diagnosed, most African governments did not perceive it as a serious macro issue that could have significant impact on a country's development efforts. To the contrary, it was regarded and treated like any other health issue, confined to the health sector. Nevertheless, as it has turned out, AIDS has become a full-blown development crisis. Its social and economic consequences are felt widely not only in health but in education, industry, agriculture, transport, human resources and the economy in general.

Table 1: Numbers of people (millions) worldwide living with HIV and AIDS in 2001

Adults and children Adults and children infected Prevalence (\%) Region living with HIV/AIDS with HIV in past 12 months among adults

Sub-Saharan

Africa

North Africa and

Middle East

Rest of the world

Total

Source: UNAIDS 2001
28.1

0.4

11.5

40.0
3.4

0.1

1.5

5.0
8.4

0.2

0.4

9.0

In Kenya, the pandemic has mainly targeted those in the productive and reproductive age categories. The prevalence rate among adults has reached double - digit figures and continues to rise. In Kenya 15\% of the adult population (15-49 years) are living with HIV/AIDS (UNAIDS 2002). HIV/AIDS is fast eroding the health benefits, 
which Kenya gained in the first two decades after independence. Poverty Reduction Strategy Paper for the Period 2001-2004 indicates that current trends in health indicators are less optimistic as evidenced by high child and maternal mortality rates and declining life expectancy. HIV/AIDS is a national threat to poverty alleviation and economic recovery strategies (GOK, 1997).

The role of human capital in economic development is now widely accepted, particularly in the context of the endogenous growth models. HIV/AIDS destroys the human capital (Bonnel, 2000). A healthy population is key to economic growth and therefore economic development. Health has a positive and significant effect on economic growth (Bloom, et al., 2001). However, the relationship between HIV/AIDS and economic growth is complex, especially when considering the fact that HIV/AIDS has wider effects beyond health. It is exceptionally difficult to gauge the economic impact of the epidemic. Many factors apart from AIDS affect economic performance and complicate the task of economic forecasting - drought, internal and external conflict, corruption and economic mismanagement. Moreover, economies tend to react more dramatically to economic restructuring measures, a sudden fuel shortage, or an unexpected change of government, than to long, slow difficulties such as those wrought by AIDS.

Nevertheless, the impact of HIV/AIDS on economic development is multifaceted and not necessarily direct. Perhaps that in itself partly explains why there is paucity of empirical studies on the impact of HIV/AIDS on economic growth. There is no doubt HIV/AIDS has affected Kenya's economic performance and is bound to hamper the future development. There is growing evidence that as HIV prevalence rates rise, both total and growth in national income - gross domestic product, or GDP of a country -fall significantly.

This paper explores the channels and transmission mechanisms through which HIV/AIDS affects economic growth using Kenya as an illustrative example. Within this framework, the paper attempts to analyse the impact of HIV/AIDS pandemic on Kenya's economic performance at a macro level using a macroeconomic model for the Kenyan economy - the KIPPRA-Treasury Macro Model (KTMM) - to simulate the effects. We need to understand these broader economic effects to be able to form an effective policy response. 
The remainder of this paper is organised as follows: Section two gives brief literature on HIV/AIDS in Kenya, section 3 highlights Kenya's economic performance and section 4 explains the causal relation between poverty and HIV/AIDS. The channels through which HIV/AIDS affects economic growth including effects on productivity growth are described in section 5. Impact on economic growth and simulation results are explained in section 6 while section 7 concludes.

\section{HIV/AIDS IN KENYA}

Since 1984, when the first case of AIDS was diagnosed in Kenya, infection rates have grown quite rapidly spreading to almost every part of the country (NASCOP, 1999). The number of new AIDS cases reported in a year has been on average 12,000 since 1990. By the end of 1995, the National AIDS/STD Control programme (NASCOP) reported over 63,000 cumulative cases of AIDS. However, due to under reporting, missed diagnosis and delays in reporting, reported cases only represent the tip of the iceberg.

The information on HIV/AIDS prevalence in Kenya is based on sentinel HIV tests on women (age 15-49) presenting themselves for prenatal care at selected sites in the country. The sample from which the HIV data is derived is not representative of the entire population. Nevertheless, the sentinel data is the best information available about the prevalence of the disease, supplemented by routine data from governmental hospitals, Voluntary Counselling centres (VCTS) and Non-Governmental Organisations (NGOs) dealing with HIV/AIDS.

Using the sentinel data (see table 2), $13 \%$ of the population was estimated to be HIV positive in 1999. In 2002, the national prevalence rate was estimated to have declined from $13.4 \%$ in 2000 to around $10 \%{ }^{1}$, but some districts have prevalence rates of over $30 \%$ (see table 3). Although the prevalence rate is higher in urban areas, most of the

\footnotetext{
${ }^{1}$ There is consensus within the Ministry of Health in Kenya that HIV/AIDS prevalence has declined, but there is no agreement on the cause of the decline. It is also unclear whether the decline is permanent.
} 
infected people are in rural areas. However, it was not until 1999 that AIDS was officially declared a national disaster in Kenya.

Table 2: Estimated HIV Prevalence, 1998 - 2002

\begin{tabular}{|l|l|l|l|l|l|}
\hline Prevalence (\%) & $\mathbf{1 9 9 8}$ & $\mathbf{1 9 9 9}$ & $\mathbf{2 0 0 0}$ & $\mathbf{2 0 0 1}$ & $\mathbf{2 0 0 2}$ \\
\hline Urban & 18.1 & 17.8 & 17.5 & 17.0 & 16.5 \\
\hline Rural & 13.0 & 13.0 & 13.0 & 13.0 & 12.5 \\
\hline Total & 12.5 & 13.0 & 13.4 & 13.0 & 10.2 \\
\hline
\end{tabular}

Source: GOK, 2003

It is now estimated that 2.2 million Kenyans were infected by HIV by the year 2002 (GOK, 2003). In addition, based on the supplementary information, it is estimated that an average of 864 Kenyans die each day because of the disease. There are 700,000 to 1 million HIV/AIDS orphans. Coupled with poor economic performance and widespread poverty with $56 \%$ of population living below the poverty line by the end of 2000, the epidemic has had its heavy toll on the economy. As acknowledged in the Sessional Paper Number 4 on AIDS in Kenya, 1997, the disease has a negative effect on life expectancy, infant mortality, adult mortality and dependency ratios.

The HIV/AIDS is disproportionately affecting those persons aged $15-49$ years who are in their most productive age category. The prevalence of AIDS cases has been found to peak at around ages 25-29 for females and 30-34 for males. Figure 1 shows that there were more females between age 15-29 infected with HIV/AIDS compared to men. However, there were more men than women with HIV/AIDS at age 30 and above for the period 1986-2000. Since women begin child bearing at an early age, especially as evidenced by the rampant teenage pregnancies, this has implications on their biological roles, for example mother-to-child virus transmission, HIV orphan children, etc. Table 3 shows that the percentage of pregnant women testing positive at urban sentinel surveillance sites was relatively higher for Busia, Kisumu, Meru and Thika districts. 
Figure 1: Age-sex distribution of reported AIDS cases (1986-2000)

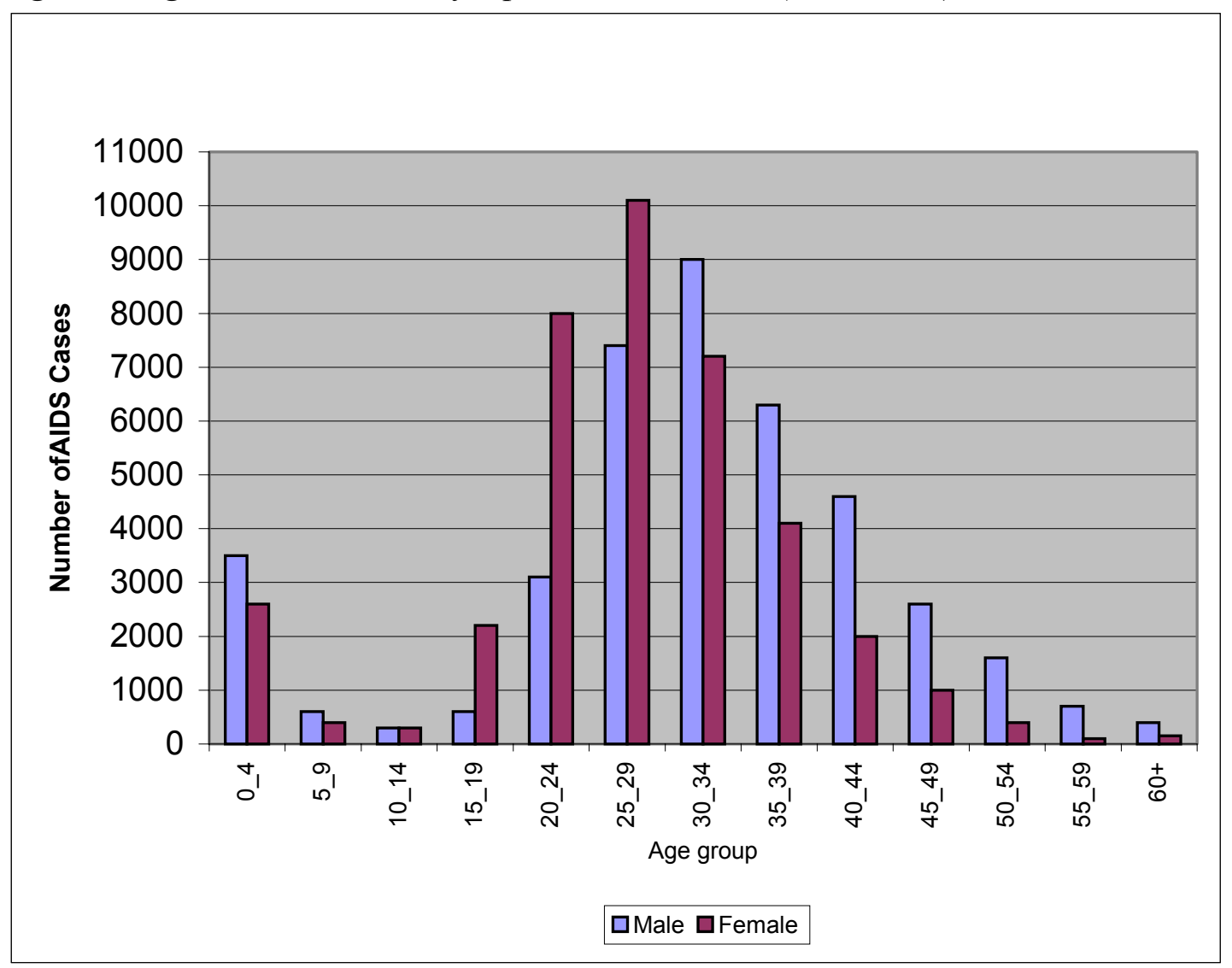

Table 3: Percentage of pregnant women testing positive at urban sentinel surveillance sites

\begin{tabular}{|l|l|l|l|l|l|l|l|l|l|l|l|}
\hline Urban Site & $\mathbf{9 0}$ & $\mathbf{9 1}$ & $\mathbf{9 2}$ & $\mathbf{9 3}$ & $\mathbf{9 4}$ & $\mathbf{9 5}$ & $\mathbf{9 6}$ & $\mathbf{9 7}$ & $\mathbf{9 8}$ & $\mathbf{9 9}$ & $\mathbf{0 0}$ \\
\hline Busia & 17 & 10 & 30 & 22 & 23 & 22 & 28 & 29 & 30 & 34 & 22 \\
\hline Garissa & 5 & - & 5 & 4 & 15 & 6 & 5 & 8 & 6 & 6 & - \\
\hline Kajiado & - & - & - & - & - & 6 & 7 & 10 & 8 & - & - \\
\hline Kakamega & 5 & 13 & 15 & 9 & 14 & 12 & 10 & 10 & 16 & 12 & 12 \\
\hline Kisii & 2 & 4 & 0 & 3 & 9 & 4 & 16 & 16 & 15 & 12 & 16 \\
\hline Kisumu & 19 & 19 & 20 & 20 & 30 & 25 & 27 & 33 & 29 & 27 & 35 \\
\hline Kitale & 3 & 6 & 21 & 8 & 11 & 10 & 12 & 13 & 10 & 18 & 17 \\
\hline Kitui & 1 & 5 & 2 & 8 & 20 & 4 & 4 & 6 & 10 & 9 & 14 \\
\hline Meru & 3 & - & - & 2 & 11 & 9 & 16 & 14 & 23 & 30 & 35 \\
\hline Mombasa & 10 & 17 & 11 & 17 & 11 & 16 & 12 & 17 & 16 & - & 12 \\
\hline Nakuru & 10 & 13 & 13 & 23 & - & 27 & 11 & 25 & 25 & 27 & 11 \\
\hline Nyeri & 3 & 4 & 9 & 3 & 6 & - & 9 & 7 & 17 & - & 14 \\
\hline Thika & 3 & 10 & 3 & 28 & 40 & - & 13 & 19 & 33 & 18 & 21 \\
\hline
\end{tabular}

Source: NASCOP, 2001

The Government of Kenya has recently intensified its efforts to reduce the spread of HIV/AIDS epidemic through a host of programmes including collaboration with Non Governmental Organisations, to set up Voluntary Counselling and Testing Centres (VCTs) across the country and creating awareness about the dangers of the epidemic. 
This has resulted in a reduction in the prevalence rates (see Table 2) at the national level, though the urban rates still surpass the rural rates and there are wide regional disparities. In April 2003, the president commissioned a Parliamentary Committee, which he himself chairs, to look into the issues of HIV/AIDS. With this it is hoped that the epidemic will be brought under control.

\section{KENYA'S ECONOMIC PERFORMANCE}

The period from independence (1963) to 1973 witnessed the most rapid economic growth in Kenya's history. Gross Domestic Product (GDP) grew at an average of $6.6 \%$ and per capita income remained positive despite high population growth rates. The 1960s and 1970s were predominantly characterized by controls in virtually allkey sectors. This approach seems to have worked well as evidenced by the remarkable growth. There was expansion of output and employment propelled by expansionary fiscal policy. By the 1980s, Kenya had achieved a reasonable level of industrialization by regional standards (Lall and Pietrobelli, 2002). The crude death rate was dropping rapidly in Kenya. Life expectancy was rising steadily. Table 4 shows the demographic indicators in Kenya since independence. The table shows that infant mortality stood at 74 deaths per 1000 live births and under five was 112 per 1000 live births by end of 1996.

However, with a series of external shocks in the 1970s, the economic performance started dwindling and the inefficiency and inadequacy of the import-substitution policy became evident. For instance, the oil shocks of the 1970s, compounded by the mismanagement of the 1976-77 coffee boom, and the collapse of the East African community caused acute balance of payment problems. Substantial reforms, which were supported by the Bretton Woods Institutions, were implemented in the 1980s and 1990s, although the record of implementation was patchy and marked by many episodes of policy reversal. 
Table 4: Demographic Indicators 1963 - 2000

\begin{tabular}{|l|l|l|l|l|l|l|l|l|l|}
\hline & 1963 & 1979 & 1984 & 1989 & 1992 & 1993 & 1994 & 1996 & 2000 \\
\hline $\begin{array}{l}\text { Population } \\
\text { (millions) }\end{array}$ & 8.9 & 15.3 & 18.4 & 21.4 & - & 24.5 & 26.0 & - & 30 \\
\hline Fertility rate & 6.8 & 7.9 & 7.7 & 7.7 & 6.7 & 5.4 & 4.9 & 5.3 & 4.7 \\
\hline $\begin{array}{l}\text { Crude death } \\
\text { rate/1000 }\end{array}$ & 20.0 & 14.0 & 13.0 & 12.0 & 12.0 & 10.0 & - & 13 & 14 \\
\hline $\begin{array}{l}\text { Crude birth } \\
\text { rate/1000 }\end{array}$ & 50.0 & 52.0 & 50.0 & 49.0 & 50.0 & 46.0 & - & 45 & 44 \\
\hline $\begin{array}{l}\text { Life } \\
\text { Expectancy } \\
\text { birth (yrs) }\end{array}$ & 44.0 & 54.0 & 56.0 & 58.0 & 60.0 & 60.0 & - & 58 & $58(55)$ \\
\hline $\begin{array}{l}\text { Infant } \\
\text { Mortality rate }\end{array}$ & 120 & 104. & 87.0 & 74.0 & 68.0 & 62.0 & 59.0 & $60(74)$ & $77(87)$ \\
\hline $\begin{array}{l}\text { Under-5 } \\
\text { mortality } \\
\text { rate/1000 }\end{array}$ & 0 & - & 92 & 94.0 & 108. & 99.0 & - & $110(112)$ & $75(115)$ \\
\hline $\begin{array}{l}\text { Adult } \\
\text { prevalence\% }\end{array}$ & - & - & 3.1 & 4.7 & 5.3 & 6.7 & 8.5 & 13.4 \\
\hline Source: Goverv & 0 & & & & & \\
\hline
\end{tabular}

Source: Government of Kenya, 1998

However, economic Performance did not improve as evident in table 5.

Table 5:Average Annual Growth Rates (\%) of Real GDP, 1964-2002

\begin{tabular}{|l|l|l|l|l|l|l|}
\hline Sector/year & $1964-73$ & $1974-79$ & $1980-89$ & $1990-95$ & $1996-99$ & $2000-02$ \\
\hline Agriculture & 4.6 & 3.9 & 3.3 & 0.4 & 1.3 & -0.1 \\
\hline Manufacturing & 9.1 & 10.0 & 4.8 & 3.0 & 1.3 & 1.1 \\
\hline $\begin{array}{l}\text { Finance, Real Estate } \\
\text { etc }\end{array}$ & 9.8 & 12.4 & 6.8 & 6.6 & 3.9 & 2.3 \\
\hline Government Services & 16.9 & 6.5 & 4.9 & 2.6 & 0.8 & 6.6 \\
\hline GDP & 6.6 & 5.2 & 4.1 & 2.5 & 1.9 & 0.7 \\
\hline
\end{tabular}

Source: Government of Kenya, Economic Survey various issues 
GDP growth declined in virtually all sectors. Given the population growth rates of about $2 \%$ per annum in recent decades, it is evident that real per capita income has been on decline since the mid-1990s. Key macro aggregates (see table 6) shows that growth performance has remained depressive in the 1990s and in the new millennium, with a declining growth in investments (both private and public) and exports. This partly accounts for the declining wage employment in the formal sector, leading to a surge in the informal sector employment.

Table 6: Performance of key real macroeconomic aggregates

\begin{tabular}{|l|l|l|l|l|l|}
\hline Variable & $\begin{array}{l}\mathbf{1 9 7 5 -} \\
\mathbf{7 9}\end{array}$ & $\mathbf{1 9 8 0 - 8 4}$ & $\begin{array}{l}\mathbf{1 9 8 5 -} \\
\mathbf{1 9 8 9}\end{array}$ & $\mathbf{1 9 9 0 - 1 9 9 6}$ & $\mathbf{1 9 9 7 - 2 0 0 1}$ \\
\hline (\% Volume change) & & & & & \\
\hline GDP & 5.6 & 3.2 & 5.7 & 2.3 & 1.2 \\
\hline Private investments & 3.2 & 0.9 & 10.2 & 1.3 & 0.4 \\
\hline Government investments & 5.9 & 0.5 & 9.3 & 5.4 & -0.5 \\
\hline Exports & -1.9 & 0.6 & 6.2 & 7.1 & 2.0 \\
\hline Imports employment- & 0.3 & -5.5 & 8.4 & 9.5 & 1.8 \\
\hline $\begin{array}{l}\text { Wage } \\
\text { private sector (\% change) }\end{array}$ & 0.8 & 4.0 & 3.5 & 1.5 \\
\hline Population (in millions) & 14.1 & 17.1 & 20.3 & 24.0 & 29.5 \\
\hline
\end{tabular}

Source: KTMM

While the poor performance cannot be solely attributed to the impact of HIV/AIDS, the pandemic has exacerbated the situation and its concealed effects might adversely affect future economic progress. Although the first case was identified in 1984, the economic burden of HIV/AIDS is likely to have become significant from the early 1990s, given the incubation period and the fact that high rates of infection were noted in the 1990s. As pointed out in the Kenya's PRSP, the pandemic accounts for the increase in poverty, through loss of productive members of the labour force, AIDS orphans, population size and growth, cost of health care and child mortality. However, only scattered information is available about the economic effects of HIV/AIDS in the country.

\section{HIV/AIDS AND POVERTY}

Poor health, particularly by HIV/AIDS, has been cited as a major cause of poverty, affecting poor people's productivity. A two-way causal relationship between poverty and AIDS can be postulated. Poverty increases the vulnerability to HIV/AIDS 
especially for females, which through its impact on productivity and loss of life of the economically productive members of the society, exacerbates the poverty situation.

Despite numerous policies, poverty still remains widespread in Kenya, afflicting disproportionately more women than men (Kimalu, et al., 2002). The national poverty rate estimated at $52.3 \%$ in 1997 had increased to $56.8 \%$ by 2000 with wide regional disparities (Mwabu et al., 2002). In general, the prevalence of poverty among femaleheaded households is relatively higher than in male-headed ones. Poverty levels are slightly more severe for female-headed households whose husbands are away as illustrated in Figure 2.

Figure 2: Poverty by type of household

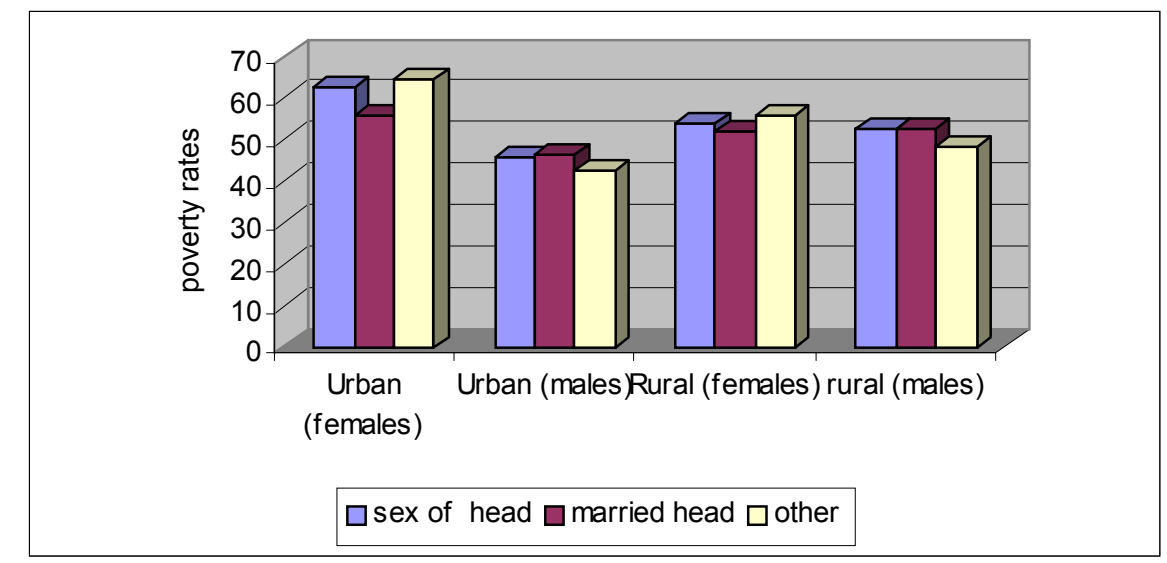

Source: GOK 2000b

Note: 'other' for female refers to household who is female and married but husband away for over 3 months. 'Other' for male single, divorced/widowed.

The dynamics of HIV/AIDS and poverty are best comprehended at the micro level. At the household level, the cost and income losses due deaths are devastating but also have serious implications on the macro economy. First, the costs of care of the HIV/AIDS patients deplete the family's savings, sometimes resulting into debts and sale of family assets. Loss of income could imply reduced consumption, resulting to low demand for goods and services and hence low production and investment. Deaths of breadwinners increase the poverty situation and vulnerability at the household level, which in itself might facilitate the spread of the virus due to increased vulnerability. Moreover, death of parents results in rising number of orphans, who have to rely on the society for their welfare hence causing further strain on economic resources. Many a time, such children are unlikely to afford better health care and education, which perpetuates the poverty situation. 


\section{HIV/AIDS AND ECONOMIC GROWTH}

The impact of HIV/AIDS on economic growth is not only multifaceted but also turns out to be partly concealed, with effects both in the short run and long run. HIV/AIDS also has direct effects on output, as well as future economic development. Moreover, there could be two-way causal effects between HIV/AIDS and development resulting in a vicious development cycle in which HIV/AIDS undermines growth, which in turn exacerbates the spread of the pandemic further reducing economic growth. The impact is mainly analysed in terms of HIV/AIDS effects on main determinants of growth. For instance, Bonnel (2000) points out impact on three main determinants of economic growth, namely physical, human and social capital.

Broadly, channels through which HIV/AIDS affects economic growth can be grouped into the following categories: asset accumulation and technological channels, gender channel and inter-sectoral channel. The economic effects of HIV/AIDS through these channels are mediated by prevailing institutions such as labour and capital markets, customs and traditions that mandate social roles for women, property rights regimes (for instance, whether women can own property or be inherited), social networks and sectoral linkages. It is these institutions (markets, customs, property rights, social networks and sectoral linkages) that determine the magnitudes of the observed macroeconomic effects of the HIV/AIDS e.g. the growth rates, poverty rates, income inequalities etc. The channels are briefly expounded below.

\subsection{Asset accumulation and technological channels}

\subsubsection{Human capital}

HIV/AIDS not only destroys the built up stock of human capital but also affects the future stock of capital as a result of low investments and high replacement costs. HIV/AIDS appears to target the economically and socially active age group, which is relatively highly skilled and experienced. The pandemic cuts short the productive lives of this critical age group. This has effects on the economic production. In aggregate production function, deaths due to AIDS lower growth by reducing the skill level of the labour force. Moreover, the mortality and morbidity of the skilled workers 
(teachers, scientists, doctors, and entrepreneurs) retards the technical progress (innovation).

\subsubsection{Physical capital}

Morbidity and mortality rates due to HIV/AIDS reduce the stock of physical capital. HIV/AIDS is one of the most costly diseases. Once it strikes it divert resources from capital formation to health care provision and other expenses relating to healthcare provision - screening, opportunistic infections, keeping patients in hospitals and drugs (anti-retroviral whose cost is still out of reach for many in Kenya and in Africa as a whole)- and even funeral expenses. At infection, resources will be shifted from productive investment to health sector expenditures and health care. Over time, economic development is affected to the extent that the pandemic diverts resources away from investments and reduces domestic savings.

HIV/AIDS scourge has exerted enormous strain on the health care budget. The public Health system is already operating at capacity with many hospitals overcrowded and beds frequently double/triple occupied while others sleep on the floor. Due to the hard budget constraints, the government is not able to give adequate health care budgetary provisions that conform to the population growth. This, coupled with the cost sharing policy, makes healthcare services unaffordable by the poor, majority of who are women. HIV/AIDS increases the number and percentage of people seeking healthcare services, and increases the costs of health care. This reduces the money available for the prevention and treatment of other illnesses. This further affects the human capital formation. In Kenya most AIDS patients receive treatment from government hospitals, which have the highest number of beds $(46.3 \%)$, followed by private hospitals (28.8\%), and mission hospitals (24.9\%). Adolescent health is also a key concern in Kenya as teenage pregnancies, abortions, sexually transmitted diseases including AIDS are common health issues pertinent to the youth. For instance a case study by Were (2000) in Busia district showed that about 33\% of antenatal mothers who visit public health facilities are teenagers.

At the family or household level, the loss of income (and stream of future incomes) as a result of death and the cost of care deplete the family's savings and resources. This is likely to lead to low demand for goods and services and low investment in health, 
education and physical assets. The effect is reflected at the macro level, implying low savings and fewer resources for investment. Over time, the pandemic depletes savings both at the domestic and macro levels. This could be partly mitigated by external financing but this is unlikely to be the case of Kenya, which has been experiencing external financing problems. Reliance on domestic financing through government borrowing will certainly worsen the budget deficits.

\subsubsection{Social capital}

Loss of lives and the resultant psychological, physical and financial stresses tampers with the social structures and the ability to produce social capital. HIV/AIDS affects the social structures and traditional support mechanisms, which are considered very critical especially in the African setting. The stigma attached to HIV/AIDS reduces social interactions and networking among workers. Stigmatisation of people living with HIV/AIDS may not only reduce social capital but may also stifle innovations. HIV impairs networks and reduces incentive to invest in information and new networks, especially those that promote and sustain economic growth (McPherson 2003). Social capital is important for the efficiency and productivity of the productive sectors of the economy. Thus, this could slow down the process of production and capital accumulation in the economy, which in turn affects growth and development. HIV infections and deaths also lower (short run) growth by retarding technical progress, reducing accumulation of assets or both.

\subsection{Gender channel}

Women are at greater risk of HIV infection than men because of the their lower socioeconomic status. Women's lower socio-economic status in Africa makes them more vulnerable to HIV infections either because they lack bargaining power in sexual relationships or in marriage markets. Their socially determined roles also increase vulnerability and are associated with adverse effects of HIV/AIDS. Custom may mandate certain occupations for women-e.g. most women in Africa work in the subsistence agriculture and in low-productivity informal or service sectors. Since these activities fall outside the small modern sector (for which data is available), productivity effects of HIV/AIDS are in all probability understated. The understatement has the effect of suppressing the economic burden of HIV/AIDS 
borne by women with the consequence that no social policy is taken to alleviate the burden. Here, HIV/AIDS is a cause of poverty, especially among women. Moreover, gender inequalities and socially determined women's roles in the 'care economies' have implications on the efficiency and productivity of the macroeconomy ${ }^{2}$ (see Were and Kiringai 2003).

\subsection{Inter-sectoral channel}

Effects of HIV/AIDS in one sector e.g. reduction in the agricultural output are felt in other sectors such as agro-based manufacturing sector. These multiplier effects can be very large and their magnitudes depend on the extent to which the sectors are linked to each other by transport, communication or other distributional channels. Deaths of teachers through HIV/AIDS, for instance, have effects beyond the education sector. In most African countries including Kenya, agriculture as the main stem of the economy is highly inter-linked with other sectors.

\subsection{HIV/AIDS and productivity growth}

Perhaps one of the likely direct links between AIDS and economic growth is through its impact on productivity, which in turn affects economic growth. In the short run, the effect of HIV/AIDS on human, social and physical capital is likely to manifest itself in terms of productivity. The impact of HIV/AIDS is here analysed in terms of impact on productivity and its effects on economic growth.

\subsubsection{Impact on Working Population}

One of the most devastating characteristics of HIV/AIDS is that majority of the people who are infected are in the most productive years of their lives. This group constitutes the highest proportion of the working population. In Kenya HIV has struck the professionals (teachers, scientists, doctors, entrepreneurs, etc), as well as skilled and unskilled labour force. This could imply a reduced pool of trained and skilled labour since it is costly, in terms of time and money, to replace skilled labour force.

\footnotetext{
2 'Care' or 'household' economy refer to the unpaid work or activities such as domestic work, voluntary community work, care for the sick and elderly etc, as opposed to 'productive activities' which refers to income generating activities, generally linked to the market.
} 
Kenya has a labour force of about 13.9 million, which comprises people aged 15 to 60. Employment in the formal sector (wage employment) constitutes only a small proportion of Kenya's labour force. The majority of the people are employed in the informal sector. Growth in wage employment in the last six years has almost stagnated, partly due to the poor economic performance of the economy. The number of people in wage employment in 2000 was about 1.7 million. Agriculture and forestry, manufacturing and service sectors account for a large proportion of wage employment.

\subsubsection{Impact on productivity of Women}

It is well acknowledged that HIV/AIDS has gender differential impacts, with females being more vulnerable. At the same time, it is also recognised that empowerment of women (through greater economic independence) is associated with a lower HIV prevalence rate (Bonnel, 2000). Hence the assessment of HIV/AIDS impact on economic development would be incomplete without recognising the differential gender roles and effects. Gender as an issue cuts across all the sectors. However, given the societal gender roles and the reproductive roles of women, there are genderspecific effects and interventions. For instance, the high infections and vulnerability to HIV/AIDS affects the role of women in food production and production of social capital in the 'care' economy (Çagatay, 2000). Only a small number of women are engaged in the formal sector and therefore the majority are mainly engaged in the informal sectors of the economy that are not likely to be captured in the country's Social National Accounting (SNA). Blackden and Bhanu (1999), estimate that $60 \%$ of female activities in Kenya are not captured in the SNA. Given that a substantive amount of productive work by women is not captured in the SNA data, the impact on HIV/AIDS on economic development could be grossly underestimated.

High levels of poverty and cost of healthcare provision for HIV/AIDS patients in the health facilities have crowded out majority of Kenyans from Medicare - shifting the burden of care to women who take over from hospitals and other healthcare providers. Even if they are not infected, the time and resources spent on caring for HIV/AIDS patients reduces women's productivity both in the informal and formal sectors, as well as their critical role in production of social capital in the 'care' economy. 
Moreover, their vulnerability to the scourge is increased through their reproductive roles. The increasing number of HIV/AIDS cases and the resultant number of widows and orphans has increased women's workload and their financial responsibilities significantly (USAID 2002). This affects not only their direct economic contribution but also the indirect roles of production of social capital, which is a key factor in the efficiency of the productive sector.

Women's burden in terms of healthcare is worsened by the fact that primary and preventive health care are grossly under-funded, leading to poor health services at the community level (GOK 2000). Due to their vulnerability, women and children are the major beneficiaries of such services and are therefore the most affected by lack of proper healthcare services. Thus, child and maternal mortality rates are still relatively high, with wide regional variations. Estimates of maternal mortality rates range between 200-600 per 100000 live births.

It is likely that hospitalisation and death from opportunistic illnesses such as tuberculosis conceal the number of HIV/AIDS deaths. The impact of HIV/AIDS particularly on women due to their high vulnerability and the resultant escalating levels of AIDS orphans is underestimated. Low productivity among the female, both in urban and rural areas is likely to be aggravated by the HIV/AIDS scourge, hence affecting economic growth.

\subsubsection{Impact on manufacturing Firms and other work places}

The HIV/AIDS epidemic lowers the productivity of labour and increases costs. In the industrial sector, the direct effects of HIV/AIDS can be observed both in terms of productivity and extra costs associated with the disease. HIV/AIDS morbidity and mortality has impacted negatively at the work place through increased absenteeism, increased staff turnover, loss of skills and experienced staff, and declining staff morale (AIDSCAP, 1996). All these effects have a direct effect on productivity and production capacity. Sick-offs and absenteeism occur mainly as a result of the illness or need to attend to sick family member(s), attend funeral services, etc. Poor work morale is due to psychological and financial stress associated with the pandemic. 
Extra costs to a firm arise as a result of costs related to medical care, health insurance, training and recruitment costs, employee benefits, burial expenses, among others. The workers' productivity loss compromises the profits, which are further reduced by high medical costs. These reduce the firm's profits and further investments. In avoidance of such costs, most firms turn away highly skilled personnel on the basis of the HIV status, foregoing their skills and associated production gains. Reports from some sugar companies in Kenya's sugar belt located at a region with the highest HIV prevalence rates have indicated that approximately one in three employees is HIV positive. A case study of firms illustrates some of the effects of HIV/AIDS in the business sector (Box 1 ).

\section{Box 1: A case study of five companies}

In 1994 AIDSCAP conducted a study on five companies involved in transport, manufacturing/light assembly, textiles, wood processing and agro-business with an average of 1500 employees. High HIV/AIDS-related expenditure was associated with health-care, burial fees and recruitment. The companies experienced decreased revenue through decreased productivity caused by absenteeism and funeral attendance, lost production during recruitment and orientation of new employees. The firms had spent Ksh 1,250 per employee for AIDS- related costs and this was projected to rise to Ksh. 2,850 per employee by the year 2005. The additional cost of AIDS could increase the cost of labour by $3 \%$ to $8 \%$ in the five companies by year 2005 .

\subsubsection{Impact on Agriculture}

The agricultural sector employs $80 \%$ of the labour force and accounts for about $30 \%$ of the country's GDP and 70\% of Kenya's export earnings. Hence the impact of HIV/AIDS just on the agricultural sector's economic contribution alone cannot be overemphasised. This sector has been the most affected by HIV/AIDS resulting in a huge loss of production. The majority of people who work in the agricultural sector, particularly in the rural areas are women. Considering the impact of HIV/AIDS on women and the role of women especially in food production, food security and export production are at threat. In general, HIV/AIDS has also adversely affected production and productivity in virtually all the sectors of the economy, most notably agriculture, manufacturing and service industry. 


\section{QUANTIFYING THE IMPACT OF HIV/AIDS ON GDP GROWTH}

Ideally, to measure the growth effect of HIV/AIDS properly, one has to control for effects of other diseases. In the literature, the controls are never implemented. Moreover, exact data on deaths from HIV/AIDS are not available. Deaths are often classified according to the opportunistic diseases e.g. tuberculosis, cancer, bronchitis etc. Thus, the measured effects are burden of illness (or death from any illness, not from AIDS). Estimating the effects of the various interdependent effects of HIV/AIDS on economic performance is undoubtedly a complex task. Thus, it is not surprising that only a few studies have attempted to quantify the effects of HIV/AIDS on GDP in Africa (see Dixon, et al., 2002 for a summary of studies). The few attempts using simple regression analysis and computable general equilibrium models predict a negative net effect on the growth of GDP per capita.

Using a macro-econometric model for the Kenyan economy-the KIPPRA-Treasury Macro Model (KTMM) - we generate simulations to help understand and assess the macro effects of HIV/AIDS (see Box 2 for a synopsis of the model). From the different channels explored, attempts are made to quantify the effects of HIV/AIDS based on the available information. The model is then used to simulate the effects. We concentrate on the implications of the pandemic for the medium-term growth prospects, since this is a model for medium-term projections. We consider only three channels as elaborated and estimated below, with a summary in Table $5^{3}$. That is, labour productivity in the formal private sector, lost earnings from wage employment and the opportunity cost of the additional public health expenditures associated with HIV/AIDS.

Before proceeding further, it is worth noting that a macroeconomic model like the KTMM is highly aggregated and the data used is mainly based on Systems of National Accounts (SNA). Thus, analysis is mainly focused on the aggregate formal sectors - based on data availability. Unfortunately this may not be a representative picture of the informal sector where a significant proportion of the labour force is employed. Detailed micro simulations are possible at the sectoral levels where the data are based on surveys, which can be relatively highly disaggregated. Such models

\footnotetext{
${ }^{3}$ It is possible to consider the effects of other channels if fairly accurate estimates are available.
} 
can then interface with the macroeconomic models for precise macro effects and policy implications.

\section{Box2: The KIPPRA-Treasury Macro Model}

The KIPPRA-Treasury Macro Model (KTMM) is a macroeconomic model of the Kenyan economy, which provides medium-term projections of major macroeconomic variables in a consistent framework. More importantly, KTMM, like other macro models is vital for conducting policy analysis by way of policy simulation.

KTMM is built along the fairly familiar aggregate demand - aggregate supply (AD-AS) framework. The real side of the economy in the model contains four types of agents: domestic production (private firms, parastatals and public service sector), households, government and the rest of the world. The model contains three types of markets: labour, product and financial markets. Total demand equals the sum of investment, consumption, government expenditure and exports. Total demand minus imports equals Gross Domestic Product (GDP) at market prices. Basic prices are determined endogenously in the model: the price of goods and services, nominal and real wage, nominal and real exchange rate, and domestic nominal interest rate. Wages and prices are determined in the labour market and product markets respectively. The exchange rate and interest rates are determined in the financial market. It is assumed that the exchange rate is floating so that the money supply is available as an exogenous policy instrument. The interest rate moves to clear the money market while the exchange rate clears the market for foreign assets.

The model is demand-driven in the short run, with multiplier effects through consumption and investment. It is assumed that the price system ensures that there is excess capacity so that any demand is actually met. This is justified by the liberalised nature of the Kenyan economy. The main feedback mechanisms in the real economy works through wage-price spiral, interest rate and real exchange rate. For example, suppose there is a demand increase, the increased demand will lead to high capacity utilisation of capital and low unemployment rates, which results in wage and price increases. Assuming a non-accommodating monetary policy, the higher inflation leads to higher interest rates and a real appreciation, therefore causing a reduction of investment and exports. The drop in exports and investment reduces demand, until equilibrium is restored. The model therefore has a tendency to return to equilibrium in the medium term and in the long run (see Huizinga et al., 2001 and, Were and Karingi 2002).

\subsection{Reduced labour productivity}

The key link between AIDS and economic growth in the short run is through productivity measures and how productivity impacts on economic growth. Labour productivity is typically defined simply as output per worker/person employed. For the measurement of output, value added is usually used. Although total employment is not the best measure of labour input, its use is determined by data availability but it also provides a reasonable indication of value added per unit of labour input. 
We estimate the average labour productivity loss due to HIV/AIDS by approximating the proportion of the infected labour force in the formal (wage employment) private sector, as well as the effective work time lost due to HIV/AIDS-related illness and associated factors. ${ }^{4}$ The analysis is based on the implicit assumption-based on data availability- that worker productivity does not vary across workers and sectors. Arguably AIDS-related illness and other side effects reduce labour productivity by increasing the absenteeism, reducing concentration and the effective time input. In 2001, wage employment in the business sector constituted about 1.2 million. In the recent past, the sector has remained almost stagnant in terms of growth in employment. We approximate that about 0.3 million people in the sector might be infected. Assuming that those affected are able to deliver only $60 \%$ of effective labour input, the effective labour lost would be approximately 0.12 million (equivalent of people not producing output). If they are able to deliver $80 \%$ of the effective labour input, the effective labour loss is 0.06 million. The average would be 0.09 million (those in the initial stages of the illness are likely to put in relatively more time input than those in the later stages of the illness). Arguably, the productivity of those who are not infected might also be affected by the physiological and financial stress associated with loss of their loved ones, time-offs to attend to the sick and attend funerals, etc. Based on the estimate of 1.2 million people in wage employment in the private sector, the loss in productivity is about $7.5 \%$ (taking the average of the lower bound of 5\% and upper bound of $10 \%$ ) - see Table 7. Using the data for 2001, we can further show that if the impact of HIV/AIDS on productivity were to be taken into account, the gross value added amounting to 805,046 million worth Kenya shillings would have effectively been produced by 1.11 million (1.2-0.09) of labourers instead of 1.2. In other words, the output would be more - in this case, the value added would be Ksh. 870,320 million, implying a loss of about Ksh. 65,274 million extra value added. Similarly, the value added per worker in this case would have been Ksh. 725,266 instead of Ksh. 670,871 (the difference is about 7.5\% reduction in productivity).

\footnotetext{
${ }^{4}$ The impact of AIDS on average productivity can also be captured using a production function in which the effects of HIV/AIDS on productivity are taken into consideration in specifying the effective labour demand (see Cuddington 1993a and 1993b).
} 
Table 7: Some channels of impacts of HIV/AIDS

\begin{tabular}{|c|c|c|c|}
\hline Sector & Channel & Key variable & magnitude \\
\hline $\begin{array}{l}\text { Business sector } \\
\text { (private sector) }\end{array}$ & $\begin{array}{l}\text { HIV/AIDS } \\
\text { labour productivity } \\
\text { (wage employment), } \\
\text { which affects output }\end{array}$ & $\begin{array}{l}\text { Labour } \\
\text { productivity } \\
\text { (decline in } \\
\text { productivity)* }\end{array}$ & $5-10 \%$ \\
\hline Public/government & $\begin{array}{l}\text { HIV/AIDS diverts } \\
\text { resources away from } \\
\text { productive investments. } \\
\text { The public health } \\
\text { expenditure on } \\
\text { HIV/AIDS if invested, } \\
\text { would have generated } \\
\text { economic growth. } \\
\end{array}$ & \begin{tabular}{l}
\multicolumn{2}{l}{ Public investment } \\
(suppose the \\
additional \\
expenditure \\
invested)
\end{tabular} & $\begin{array}{l}0.5 \% \text { of GDP } \\
\text { (Ksh } 4000 \\
\text { millions) }\end{array}$ \\
\hline $\begin{array}{l}\text { Households/ } \\
\text { business sector }\end{array}$ & $\begin{array}{l}\text { Loss of income due to } \\
\text { deaths (occurring in the } \\
\text { wage employment) and } \\
\text { high caring costs. This } \\
\text { income could have been } \\
\text { used on consumption of } \\
\text { goods and services, or } \\
\text { invested or saved. }\end{array}$ & $\begin{array}{l}\text { Wage earnings lost } \\
\text { ( assume a } \\
\text { reduction in private } \\
\text { consumption by } \\
\text { same amount) }\end{array}$ & $\begin{array}{l}\text { Ksh.4745 } \\
\text { millions }\end{array}$ \\
\hline
\end{tabular}

*Productivity estimates are computed as follows. That is, about $80 \%$ of people infected by HIV (approximately 2.2 million) fall in the productive age bracket of 15-64 years, which constitutes a pool of the labour force. Of this, about a quarter are likely to be in wage employment (total). But the wage employment in private sector comprise $70 \%$ of the total wage employment. Hence approximately 0.3 million might be infected with HIV/AIDS in the business sector with a formal wage employment of 1.2 million. That is, $(0.80 * 2.2 * 0.25 * 0.70=0.308)$ Assuming that these people are only able to deliver $60 \%$ of their effective labour, the effective labour lost is computed as $0.3 * 0.40=0.12$ million. Put simply, this is labour not effectively producing output. If they are able to deliver $80 \%$ of the effective labour input, the effective labour loss is $0.3^{*} .20=0.06$ million. The average is 0.09 million. Based on the estimate of 1.2 million people in wage employment in the private sector, the loss in labour productivity is $10 \%$ if those affected deliver $60 \%$ of their effective labour input $\{(0.12 * 100) / 1.2\}$ and $5 \%$ if they provide $80 \%\{(0.06 * 100) / 1.2\}$. On average, the loss in productivity is $7.5 \%$

\subsection{Simulation Results}

The starting point is the baseline (when nothing is changed). Based on varying assumptions on the key variables, the simulation results are discussed below. The changes in the variables are made in 2002 , which is taken as the base year. ${ }^{5}$ For the purpose of this paper, the impulse simulations are for one year (2002) -it is assumed that the effects occur only in that particular year. ${ }^{6}$

\footnotetext{
${ }^{5} 2002$ is here used for reference purposes, otherwise the analysis would still hold other years in the projection period..
} 


\section{i. Labour productivity}

The impact of a reduction in labour productivity by $8 \%$ on key macroeconomic variables is summarised in table 8. Growth in volume investments, exports and consumption decline by $-1.8 \%,-4.5 \%$ and $-2.5 \%$ respectively. Low productivity also results into relatively high prices (export price, investment price and consumer prices) of goods and services produced, which holding other factors constant, is associated with low demand and hence low investments and production. GDP growth rate declines by -2.6 percentage points (from the base). Real GDP per capita would decline by Ksh 102.3 (about 3\%) in

\section{Table 8:Impact of lower labour productivity}

\begin{tabular}{|c|c|c|c|c|c|}
\hline Key macroeconomic variables & 2002 & 2003 & 2004 & 2005 & 2006 \\
\hline \multicolumn{6}{|l|}{ wages and prices $(\%)$} \\
\hline real wage rate (CPI-urban based) & -7.2 & 0.9 & -0.4 & -0.6 & -2.0 \\
\hline wage rate Businesses & -4.1 & 3.0 & 3.4 & 4.1 & 2.4 \\
\hline consumer price $<\mathrm{H}>$ (change) -SNA based & 3.5 & 2.0 & 3.9 & 4.8 & 4.6 \\
\hline export price (change) & 2.7 & -1.0 & 1.8 & 2.3 & 3.4 \\
\hline import price (change) & 0.6 & 0.4 & 1.0 & 1.8 & 2.5 \\
\hline investment price $<\mathrm{B}>$ (change) & 2.2 & 2.1 & 2.9 & 3.6 & 3.2 \\
\hline \multicolumn{6}{|l|}{ volumes $(\%)$} \\
\hline volume consumption households & -2.5 & -0.5 & -1.9 & -2.0 & -1.9 \\
\hline investments Businesses & -1.8 & -2.2 & -1.4 & -2.7 & -1.5 \\
\hline export volume of goods and services by $<$ B $>$ & -4.5 & 2.7 & -2.1 & -1.6 & -2.6 \\
\hline import volume of goods and services by $<$ B $>$ & -1.1 & 0.7 & -0.3 & -0.3 & -0.8 \\
\hline gross value added Businesses & -3.1 & -0.2 & -2.2 & -2.2 & -2.1 \\
\hline gdp (market prices;1982; \% volume change) & -2.6 & -0.2 & -1.9 & -2.0 & -2.0 \\
\hline wage employment $<\mathrm{B}>(\%$ change $)$ & 5.4 & 1.4 & -0.4 & 0.3 & 0.4 \\
\hline labour productivity & -7.8 & -1.5 & -1.7 & -2.5 & -2.5 \\
\hline $\begin{array}{l}\text { purchasing power of average earner } \\
\text { rates }(\%)\end{array}$ & -7.2 & 0.9 & -0.4 & -0.7 & -2.0 \\
\hline current account balance ( $\%$ gdp m.p.) & -0.2 & -0.2 & -0.4 & -0.5 & -0.7 \\
\hline financial deficit - GFS basis (\% gdp m.p.) & -0.5 & -0.4 & -0.8 & -1.1 & -1.4 \\
\hline public expenditure (\% gdp m.p.) & 0.3 & 0.1 & 0.3 & 0.4 & 0.6 \\
\hline labour income share & 0.0 & 1.2 & 1.6 & 2.3 & 2.4 \\
\hline government domestic debt (\% gdp m.p.) & 0.3 & 0.4 & 0.8 & 1.4 & 2.2 \\
\hline return on investment & 3.6 & 2.1 & 0.9 & -0.4 & -0.4 \\
\hline \multicolumn{6}{|l|}{ labour years (millions) } \\
\hline total wage employment & 0.1 & 0.1 & 0.1 & 0.1 & 0.1 \\
\hline informal sector & -0.1 & -0.1 & -0.1 & -0.1 & -0.2 \\
\hline traditional sector & -0.2 & -0.4 & -0.5 & -0.5 & -0.5 \\
\hline \multicolumn{6}{|l|}{ millions (Ksh) } \\
\hline financial deficit (-) Central Government (GFS Basis) & -4572 & -4744 & -9403 & -14435 & -20805 \\
\hline Other variables & & & & & \\
\hline gdp per capita (constant market prices 1982) -ksh & -102.3 & -109.9 & -182.6 & -257.7 & -330.3 \\
\hline
\end{tabular}

Notes: $\mathbf{H}=$ household, $\mathbf{B}=$ Business sector, $\mathbf{G F S}=$ Government Finance Statistics

\footnotetext{
${ }^{6}$ Since HIV/AIDS has long term and cumulative effects, we can as well assume that the effects will be
} 
2002, with the decline rising to Ksh 330 in 2006 due the lagged effects ${ }^{7}$.

Wage employment goes up by $5.4 \%$. The reduction in labour productivity implies that private businesses have to employ more people due to high stuff turnover and also as need to compensate for low productivity hence increasing the costs, which eat into companies' disposable profits. Moreover, the ultimate effect of this link could also be reinforced by the fact that shortage of highly skilled and experienced manpower as a result of high HIV/AIDS morbidity and mortality rates could bid up wages. The ultimate effect of such an increase in wages depend on whether the increase is purely based the bargaining power (based on shortages) or partly based on productivity effects. If the bargaining power effect outweighs the productivity of the respective workers, the impact on investment and output is likely to be negative. As a matter of fact, data for past years show a divergence between the wage rate and labour productivity in the business sector-low productivity growth has been negative while the wage rate shows sporadic increases. It can be inferred that increases in the wage rates are unlikely to have been matched by productivity gains.

\section{ii. $\quad$ Lost incomes}

Consider a conservative estimate that on average, 700 people die each day due to HIV/AIDS ${ }^{8}$. Given the share of wage employment we can approximate that about $7 \%$ of the 700 (about 50) are likely to be in wage employment in the private sector. Moreover, due to economic strain and the social stigma associated with HIV, most firms are known to take drastic action by sacking infected workers on learning their status. There is no law yet to protect workers who are fired for contracting the ill-fated disease. Hence, it is likely that a number of the infected workers loose their livelihoods even before reaching the critical stages of death. Arguably, replacement of skilled and experienced workers may take time given the replacement costs, training, matching the skills etc. It becomes more difficult if the mortality rates due to AIDS are affecting the size and composition of the skilled labour force. Based on the 2001 data (see table 9 for changes in other years), the average annual wage in the

felt each year. However, it suffices to focus on one year.

${ }_{8}^{7}$ Assuming a population growth rate of $2.3 \%$

${ }^{8} 700$ is the number that is frequently quoted, especially in public forums. 
business sector is Ksh. 0.26 million. Therefore the income (wage earnings) lost in a year is approximately 4745 millions of Kenya shillings. ${ }^{9}$

Table 9: Increase in private consumption

\begin{tabular}{|c|c|c|c|c|c|}
\hline Key macroeconomic variables & 2002 & 2003 & 2004 & 2005 & 2006 \\
\hline \multicolumn{6}{|l|}{ wages and prices $(\%)$} \\
\hline real wage rate (CPI-urban based) & 0.0 & 0.0 & 0.1 & 0.3 & 0.3 \\
\hline wage rate Businesses & 0.0 & 0.2 & 0.7 & 1.1 & 1.3 \\
\hline consumer price $<\mathrm{H}>$ (change) -SNA based & 0.0 & 0.3 & 0.6 & 0.8 & 1.0 \\
\hline export price (change) & 0.0 & 0.1 & 0.5 & 0.6 & 0.8 \\
\hline import price (change) & 0.0 & 0.8 & 1.1 & 1.0 & 1.1 \\
\hline investment price $<\mathrm{B}>$ (change) & 0.0 & 0.5 & 0.8 & 0.9 & 1.1 \\
\hline \multicolumn{6}{|l|}{ volumes $(\%)$} \\
\hline volume consumption households & 1.3 & 0.4 & 0.3 & 0.1 & -0.1 \\
\hline investments Businesses & 0.4 & 1.9 & 0.9 & 0.3 & -0.6 \\
\hline export volume of goods and services by $<\mathrm{B}>$ & 0.0 & 1.2 & 1.4 & 0.7 & 0.4 \\
\hline import volume of goods and services by $<\mathrm{B}>$ & 0.9 & 0.4 & 0.3 & 0.2 & -0.1 \\
\hline gross value added Businesses & 0.9 & 0.8 & 0.7 & 0.3 & 0.0 \\
\hline gdp (market prices;1982; \% volume change) & 0.5 & 0.7 & 0.7 & 0.3 & 0.1 \\
\hline wage employment $<\mathrm{B}>(\%$ change $)$ & 0.2 & 0.4 & 0.5 & 0.3 & 0.0 \\
\hline labour productivity & 0.6 & 0.4 & 0.2 & 0.1 & 0.0 \\
\hline purchasing power of average earner & 0.1 & 0.0 & 0.1 & 0.3 & 0.3 \\
\hline \multicolumn{6}{|l|}{ rates $(\%)$} \\
\hline current account balance ( $\%$ gdp m.p.) & -0.3 & -0.3 & -0.3 & -0.2 & -0.2 \\
\hline financial deficit - GFS basis (\% gdp m.p.) & 0.1 & 0.2 & 0.4 & 0.5 & 0.5 \\
\hline public expenditure (\% gdp m.p.) & -0.2 & -0.3 & -0.5 & -0.6 & -0.7 \\
\hline labour income share & -0.3 & -0.4 & -0.4 & -0.3 & -0.1 \\
\hline government domestic debt (\% gdp m.p.) & -0.2 & -0.6 & -1.1 & -1.7 & -2.2 \\
\hline return on investment & 0.6 & 1.0 & 1.3 & 1.2 & 0.9 \\
\hline \multicolumn{6}{|l|}{ labour years (millions) } \\
\hline total wage employment & 0.0 & 0.0 & 0.0 & 0.0 & 0.0 \\
\hline informal sector & 0.0 & 0.0 & 0.0 & 0.0 & 0.0 \\
\hline traditional sector & 0.0 & 0.0 & -0.1 & -0.1 & -0.1 \\
\hline \multicolumn{6}{|l|}{ Million (Kshs) } \\
\hline Financial deficit (-) total Government (SNA Basis) & 724 & 2233 & 3837 & 5333 & 6585 \\
\hline \multicolumn{6}{|l|}{ Other variables } \\
\hline gdp per capita (constant market prices 1982) -ksh & 27.5 & 52.5 & 75.6 & 87.6 & 89.2 \\
\hline
\end{tabular}

Notes: $\mathrm{H}=$ household, $\mathrm{B}=$ Business sector, $\mathrm{GFS}=$ Government Finance Statistics

This income would have been spent on consumption, saved or invested. Assuming that the income worth 4745 millions of Kenya shillings would have all been spent on consumption, this would lead to an increase in growth of volume consumption by 1.3 percentage points and a slight increase in investments of $0.4 \%$. The overall effect would yield 0.5 percentage points as additional GDP growth rate. Real GDP per

${ }^{9}(50 * 365 * 0.26)$ 
capita would increase by Ksh 30 in 2002, rising to relatively higher amounts in subsequent years. The impact on GDP would be higher if we assume that the earnings would have been invested, resulting in more multiplier effects in the economy.

iii. $\quad$ Health care expenditures (utilized as public investment)

In the 1990s, the cost of hospital care for an AIDS patient was estimated at Ksh. 27,200 per year. But in 1990, the prevalence rate was only 5.3\%. In 1997 this cost was estimated at Ksh. 34,680 (direct cost) while indirect cost including lost wages amounted to Ksh. 538,560.00 (NASCOP, 1999). Given the rising cost of care and the rate of infection, these amounts may not even account for a quarter of the total cost of care. The expenditure on HIV/AIDS was projected at 6\%-15\% of GDP for 2000 . However, given the deteriorating economic performance that the country has been experiencing, we use a conservative estimate of $0.5 \%$ of GDP as part of public expenditure on HIV/AIDS health care. Suppose that this money would have been used for public investment e.g. in improving Kenya's poor infrastructure. Public investments crowd-in private investments, with further multiplier effects in the economy. Additional investment of $0.5 \%$ of GDP (approximately Ksh. 4000 million) would lead to positive change in investment volume by 1.3 percentage points in the base year. (see table 10).

Due to the crowding-in effects, the percentage volume change in investment increase by $2.6 \%$ and $1.3 \%$ respectively in the subsequent years $(2003,2004)$. Exports increase in subsequent years. Consumption and import volumes also increase initially but decline in subsequent years. Real GDP growth would increase by extra $0.8 \%$ consecutively for three years. Although the need to finance the public investment leads a budget deficit, additional growth leads to more revenues leading to a budget surplus in subsequent years. 
Table 10: public expenditure in public investment

\begin{tabular}{|c|c|c|c|c|c|}
\hline Key macroeconomic variables & 2002 & 2003 & 2004 & 2005 & 2006 \\
\hline \multicolumn{6}{|l|}{ wages and prices $(\%)$} \\
\hline real wage rate (CPI-urban based) & 0.0 & 0.0 & 0.1 & 0.3 & 0.3 \\
\hline wage rate Businesses & 0.0 & 0.2 & 0.7 & 1.2 & 1.5 \\
\hline consumer price $<\mathrm{H}>$ (change) -SNA based & -0.1 & 0.2 & 0.6 & 0.9 & 1.1 \\
\hline export price (change) & 0.0 & 0.1 & 0.5 & 0.7 & 0.9 \\
\hline import price (change) & 0.0 & 0.8 & 1.2 & 1.2 & 1.3 \\
\hline investment price $<\mathrm{B}>$ (change) & 0.0 & 0.5 & 0.9 & 1.1 & 1.2 \\
\hline \multicolumn{6}{|l|}{ volumes $(\%)$} \\
\hline volume consumption households & 0.7 & 0.6 & 0.5 & 0.3 & 0.0 \\
\hline investments Businesses & 1.3 & 2.6 & 1.3 & 0.5 & 0.3 \\
\hline export volume of goods and services by $<\mathrm{B}>$ & 0.0 & 1.3 & 1.6 & 0.9 & 0.6 \\
\hline import volume of goods and services by $<\mathrm{B}>$ & 0.8 & 0.7 & 0.5 & 0.3 & 0.2 \\
\hline gross value added Businesses & 1.0 & 1.0 & 0.9 & 0.5 & 0.3 \\
\hline gdp (market prices;1982; \% volume change) & 0.8 & 0.8 & 0.8 & 0.5 & 0.3 \\
\hline wage employment $<\mathrm{B}>(\%$ change $)$ & 0.2 & 0.4 & 0.6 & 0.3 & 0.1 \\
\hline labour productivity & 0.7 & 0.5 & 0.3 & 0.1 & 0.2 \\
\hline $\begin{array}{l}\text { purchasing power of average earner } \\
\text { rates }(\%)\end{array}$ & \multicolumn{4}{|c|}{ rates $(\%)$} & 0.3 \\
\hline current account balance ( $\%$ gdp m.p.) & -0.3 & -0.4 & -0.3 & -0.3 & -0.3 \\
\hline financial deficit - GFS basis (\% gdp m.p.) & -0.3 & -0.1 & 0.0 & 0.1 & 0.2 \\
\hline public expenditure (\% gdp m.p.) & 0.2 & 0.0 & -0.2 & -0.3 & -0.4 \\
\hline labour income share & -0.4 & -0.5 & -0.5 & -0.4 & -0.3 \\
\hline government domestic debt (\% gdp m.p.) & 0.2 & 0.1 & -0.1 & -0.5 & -0.8 \\
\hline return on investment & 0.8 & 1.3 & 1.6 & 1.6 & 1.5 \\
\hline \multicolumn{6}{|l|}{ labour years (millions) } \\
\hline total wage employment & 0.0 & 0.0 & 0.0 & 0.0 & 0.0 \\
\hline informal sector & 0.0 & 0.0 & 0.0 & 0.0 & 0.0 \\
\hline traditional sector & 0.0 & 0.0 & -0.1 & -0.1 & -0.1 \\
\hline \multicolumn{6}{|l|}{ Million Ksh } \\
\hline financial deficit (-) central Government (GFS basis) & -3280 & -1913 & -418 & 892 & 2027 \\
\hline \multicolumn{6}{|l|}{ Other variables } \\
\hline gdp per capita (constant market prices 1982) -ksh & 31.0 & 62.0 & 91.8 & 109.4 & 119.5 \\
\hline
\end{tabular}

Notes: $\mathbf{H}=$ household, $\mathrm{B}=$ Business sector, GFS=Government Finance Statistics

\section{CONCLUSION}

HIV/AIDS pandemic is a major policy issue of concern internationally, particularly in Africa where it has taken a heavy toll. In Kenya, the pandemic has mainly targeted those in the productive and reproductive age categories (15-49 years). HIV/AIDS is a threat to poverty reduction initiatives, and there is no doubt that it has an effect on the country's economic performance.

The economic impact of HIV/AIDS is mainly analysed in terms of its effects on determinants of economic development. One of the major challenges in such analysis is that the impact of HIV/AIDS is multifaceted, with effects both in the short run and long run. Moreover, there seems to be a two-way causal relationship between 
HIV/AIDS and development, resulting in a vicious development cycle. That notwithstanding, some of the key channels that are worth exploring are the impact of HIV/AIDS on productivity and labour force supply, production of stock of human capital; savings and investment (physical capital), HIV/AIDS-poverty nexus and HIV/AIDS-gender link.

Using the KTMM, simulation results show that HIV/AIDS, through its effect on labour productivity and loss of earnings, affect economic growth. Additionally, the associated high cost of health care implies foregoing economic growth if the resources could have been invested productively. While different channels have varying economic effects, the bottom line is that HIV/AIDS is retarding economic development in a manner that has not been fully comprehended. As detailed, accurate and representative data on HIV/AIDS become available, micro level measurements and analysis would give more reliable assessments, which would also improve the macroeconomic analysis. The gravity of the HIV/AIDS in Kenya could undoubtedly be more than can be analytically captured. 


\section{References}

AIDSCAP/Family Health International (1996). "Aids in Kenya: Social Economic Impact and Policy Implications.” U.S.A

Bloom, D., D. Canning, and J. Sevilla (2001). "The Effect of Health on Economic Growth: Theory and Evidence." Working Paper 8587. Massachusetts: National Bureau of Economic Research.

Bonnel, R. (2000). "HIV/AIDS and Economic Growth: A global Perspective", The South African Journal of Economics, Vol. 68:5.

Blackden, C. M. and C. Bhanu (1999). "Gender, growth and poverty reduction: Special Program of Assistance for Africa, 1998. Status report on poverty in subSaharan Africa." World Bank Technical Paper No. 428. Washington, D.C.: World Bank.

Cuddington, J. T. 1993a. "Modelling the macroeconomic effects of AIDS: the dualistic, labour-surplus economy." World Bank Economic Review, Vol. 7, No.3. pp 403-417.

Cuddington, J. T. 1993b. "Modelling the macroeconomic effects of AIDS with an application to Tanzania." World Bank Economic Review, Vol. 7, No.2. pp 173189

Çagatay, N. (2000). "Engendering macroeconomics and macroeconomic policies." Working Paper Series No. 6. Social Development and Poverty Elimination Division, Bureau for Development Policy, United Nations Development Programme, United Nations.

Dixon, S., S. McDonald, and J. Roberts (2002). "The Impact of HIV and AIDS on Africa's Economic Development.” BMJ Volume 324. http:bmj.com/cgi/content/full/324/7331/232

GOK (1998). "Demographic Health Survey." National Council for population and Development, Central Bureau of Statistics: Nairobi.

GOK (2000a). “A gender analysis of health in Kenya.” A report prepared by women's Bureau/DANIDA Project, Ministry of Home Affairs, Heritage and Sports, Kenya.

GOK (2000b). " Second Report on Poverty in Kenya: Volume 1 Incidence and Depth of Poverty." Nairobi: Central Bureau of Statistics and the Human Resources and Social Services Departments with the assistance of GTZ.

GOK (2001). Poverty Reduction Strategy Paper for the Period 2001-2004. Nairobi: Government Printers. 
GOK (2003). 'Economic Survey”. Nairobi: Government printers.

Huizinga, F.; A. Geda; N. S. Ndung'u; and S. N. Karingi (2001). "Theoretical base for the Kenya Macro Model: The KIPPRA-Treasury Macro Model”. KIPPRA Discussion Paper Series, DP/11/2001, Nairobi.

Kimalu, P., N. Nafula, D. K. Manda, G. Mwabu, and M. S. Kimenyi (2002a). “A situational analysis of poverty in Kenya." KIPPRA Working Paper Series, WP/06/2002, Nairobi.

Lall, S. and C. Pietrobelli. 2002. Failing to Compete: Technology Development and Technology Systems in Africa. Edward Elgar.

Mwabu, G., M. S. Kimenyi, P. Kimalu, N. Nafula, and D. K. Manda (2002). "Predicting household poverty: a methodological note with a Kenyan example." KIPPRA Discussion paper Series, DP/12/2001, Nairobi.

USAID (2002). "A Review of Gender Issues in the USAID/Kenya Integrated Strategic Plan (ISP) 2001-2005". WID Tech. A Women in Development Technical Assistance Project.

UNAIDS (2002). "Report on the global HIV/AIDS epidemic".

UNAIDS (2001). "AIDS epidemic update" www.unaids.org/epidemic update/report dec01/index..html.

Were, M. and Karingi, S. (2002). "Better understanding of the Kenyan economy: simulations from the KIPPRA-Treasury Macro Model.” KIPPRA Discussion Paper Series, DP/16/2001, Nairobi.

Were, M. (2000). “An assessment of the determinants of early pregnancies in Kenya: the case of former Nambale Division in Busia District." A research paper submitted to Organisation for Social Sciences Research in Eastern and Southern Africa (OSSREA).

Were, M and Kiringai, J. (2003). "Gender Mainstreaming in Macroeconomic Policies and Poverty Reduction Strategy in Kenya." A Research Report for African Women's Development and Communication Network (FEMNET), Nairobi. 


\section{CESifo Working Paper Series}

(for full list see www.cesifo.de)

970 Hartmut Egger and Josef Falkinger, The Role of Public Infrastructure for Firm Location and International Outsourcing, June 2003

971 Dag Morten Dalen and Trond E. Olsen, Regulatory Competition and Multi-national Banking, June 2003

972 Matthias Wrede, Tax Deductibility of Commuting Expenses and Residential Land Use with more than one Center, June 2003

973 Alessandro Cigno and Annalisa Luporini, Scholarships or Student Loans? Subsidizing Higher Education in the Presence of Moral Hazard, June 2003

974 Chang Woon Nam, Andrea Gebauer and Rüdiger Parsche, Is the Completion of EU Single Market Hindered by VAT Evasion?, June 2003

975 Michael Braulke and Giacomo Corneo, Capital Taxation May Survive in Open Economies, July 2003

976 Assar Lindbeck, An Essay on Welfare State Dynamics, July 2003

977 Henrik Jordahl and Luca Micheletto, Optimal Utilitarian Taxation and Horizontal Equity, July 2003

978 Martin D. D. Evans and Richard K. Lyons, Are Different-Currency Assets Imperfect Substitutes?, July 2003

979 Thorsten Bayindir-Upmann and Frank Stähler, Market Entry Regulation and International Competition, July 2003

980 Vivek Ghosal, Firm and Establishment Volatility: The Role of Sunk Costs, Profit Uncertainty and Technological Change, July 2003

981 Christopher A. Pissarides, Unemployment in Britain: A European Success Story, July 2003

982 Wolfgang Buchholz, Richard Cornes, and Wolfgang Peters, On the Frequency of Interior Cournot-Nash Equilibria in a Public Good Economy, July 2003

983 Syed M. Ahsan and Panagiotis Tsigaris, Choice of Tax Base Revisited: Cash Flow vs. Prepayment Approaches to Consumption Taxation, July 2003

984 Campbell Leith and Jim Malley, A Sectoral Analysis of Price-Setting Behavior in US Manufacturing Industries, July 2003 
985 Hyun Park and Apostolis Philippopoulos, Choosing Club Membership under Tax Competition and Free Riding, July 2003

986 Federico Etro, Globalization and Political Geography, July 2003

987 Dan Ariely, Axel Ockenfels and Alvin E. Roth, An Experimental Analysis of Ending Rules in Internet Auctions, July 2003

988 Paola Conconi and Carlo Perroni, Self-Enforcing International Agreements and Domestic Policy Credibility, July 2003

989 Charles B. Blankart and Christian Kirchner, The Deadlock of the EU Budget: An Economic Analysis of Ways In and Ways Out, July 2003

990 M. Hasham Pesaran and Allan Timmermann, Small Sample Properties of Forecasts from Autoregressive Models under Structural Breaks, July 2003

991 Hyun Park, Apostolis Philippopoulos and Vangelis Vassilatos, On the Optimal Size of Public Sector under Rent-Seeking competition from State Coffers, July 2003

992 Axel Ockenfels and Alvin E. Roth, Late and Multiple Bidding in Second Price Internet Auctions: Theory and Evidence Concerning Different Rules for Ending an Auction, July 2003

993 Pierre Salmon, The Assignment of Powers in an Open-ended European Union, July 2003

994 Louis N. Christofides and Chen Peng, Contract Duration and Indexation in a Period of Real and Nominal Uncertainty, July 2003

995 M. Hashem Pesaran, Til Schuermann, Björn-Jakob Treutler, and Scott M. Weiner, Macroeconomic Dynamics and Credit Risk: A Global Perspective, July 2003

996 Massimo Bordignon and Sandro Brusco, On Enhanced Cooperation, July 2003

997 David F. Bradford, Addressing the Transfer-Pricing Problem in an Origin-Basis X Tax, July 2003

998 Daniel Gros, Who Needs Foreign Banks?, July 2003

999 Wolfram Merzyn and Heinrich W. Ursprung, Voter Support for Privatizing Education: Evidence on Self-Interest and Ideology, July 2003

1000 Jo Thori Lind, Fractionalization and the Size of Government, July 2003

1001 Daniel Friedman and Donald Wittman, Litigation with Symmetric Bargaining and TwoSided Incomplete Information, July 2003

1002 Matthew Clarke and Sardar M. N. Islam, Health Adjusted GDP (HAGDP) Measures of the Relationship Between Economic Growth, Health Outcomes and Social Welfare, July 2003 
1003 Volker Grossmann, Contest for Attention in a Quality-Ladder Model of Endogenous Growth, August 2003

1004 Marcel Gérard and Joan Martens Weiner, Cross-Border Loss Offset and Formulary Apportionment: How do they affect multijurisdictional firm investment spending and interjurisdictional tax competition?, August 2003

1005 Burkhard Heer, Nonsuperneutrality of Money in the Sidrauski Model with Heterogeous Agents, August 2003

1006 V. Anton Muscatelli, Piergiovanna Natale, and Patrizio Tirelli, A Simple and Flexible Alternative to the Stability and Growth Pact Deficit Ceilings. Is it at hand?, August 2003

1007 Reto Foellmi and Josef Zweimüller, Inequality and Economic Growth: European Versus U.S. Experiences, August 2003

1008 James S. Costain and Michael Reiter, Business Cycles, Unemployment Insurance, and the Calibration of Matching Models, August 2003

1009 Marco Runkel, Optimal Contest Design when the Designer's Payoff Depends on Competitive Balance, August 2003

1010 Donald O. Parsons, Torben Tranaes and Helene Bie Lilleør, Voluntary Public Unemployment Insurance, August 2003

1011 Rüdiger Pethig and Andreas Wagener, Profit Tax Competition and Formula Apportionment, August 2003

1012 Johan Willner, Privatisation and Public Ownership in Finland, August 2003

1013 Seppo Kari and Jouko Ylä-Liedenpohja, Taxation and Valuation of International Real Investments, August 2003

1014 James Heckman, Rosa Matzkin and Lars Nesheim, Simulation and Estimation of Hedonic Models, August 2003

1015 Biswa N. Bhattacharyay, Towards a Macro-Prudential Leading Indicators Framework for Monitoring Financial Vulnerability, August 2003

1016 J. Stephen Ferris and Stanley L. Winer, Searching for Keynes: With Application to Canada, 1870-2000, August 2003

1017 Massimo Bordignon, Luca Colombo and Umberto Galmarini, Fiscal Federalism and Endogenous Lobbies' Formation, August 2003

1018 Annette Alstadsæter, The Dual Income Tax and Firms' Income Shifting through the Choice of Organizational Form and Real Capital Investments, August 2003 
1019 Peter Fredriksson and Bertil Holmlund, Optimal Unemployment Insurance Design: Time Limits, Monitoring, or Workfare?, August 2003

1020 Kashif S. Mansori, Following in their Footsteps: Comparing Interest Parity Conditions in Central European Economies to the Euro Countries, August 2003

1021 Christoph Borgmann and Matthias Heidler, Demographics and Volatile Social Security Wealth: Political Risks of Benefit Rule Changes in Germany, August 2003

1022 Kjell Erik Lommerud, Bjørn Sandvik and Odd Rune Staume, Good Jobs, Bad Jobs and Redistribution, August 2003

1023 Patrick Karl O'Brien, The Governance of Globalization: The Political Economy of Anglo-American Hegemony, 1793-2003, September 2003

1024 Antonio Ciccone and Giovanni Peri, Skills' Substitutability and Technological Progress: U.S. States 1950-1990, September 2003

1025 Bjørn Sandvik, Optimal Taxation and Normalisations, September 2003

1026 Massimo Bordignon and Gilberto Turati, Bailing Out Expectations and Health Expenditure in Italy, September 2003

1027 José A. Herce, Namkee Ahn, Ricard Génova, and Joaquín Pereira, Bio-Demographic and Health Aspects of Ageing in the EU, September 2003

1028 John Komlos and Marieluise Baur, From the Tallest to (One of) the Fattest: The Enigmatic Fate of the American Population in the $20^{\text {th }}$ Century, September 2003

1029 Stefan Napel and Mika Widgrén, Bargaining and Distribution of Power in the EU's Conciliation Committee, September 2003

1030 Kai Li and Dale J. Poirier, Relationship Between Maternal Behavior During Pregnancy, Birth Outcome, and Early Childhood Development: An Exploratory Study, September 2003

1031 Ivar Ekeland, James J. Heckman, and Lars Nesheim, Identifcation and Estimation of Hedonic Models, September 2003

1032 Kjetil Bjorvatn and Alexander W. Cappelen, Decentralization and the Fate of Minorities, September 2003

1033 Lars-Erik Borge and Jørn Rattsø, The Relationships Between Costs and User Charges: The Case of a Norwegian Utility Service, September 2003

1034 Maureen Were and Nancy N. Nafula, An Assessment of the Impact of HIV/AIDS on Economic Growth: The Case of Kenya, September 2003 